\title{
Plant pathogens as biocontrol agents for Cirsium arvense - an answer to Müller and Nentwig
}

\author{
Michael G. Cripps', Graeme W. Bourdôt ${ }^{2}$, Karen L. Bailey ${ }^{3}$ \\ I Lincoln University, John Burton Building, Christchurch 7647, New Zealand 2 AgResearch Limited, Private \\ Bag 4749, Christchurch 8140, New Zealand 3 Agriculture \& Agri-Food Canada, 107 Science Place, Saskato- \\ on, Saskatchewan, S7N 0X2, Canada
}

Corresponding author: Michael G. Cripps (michael.cripps@lincoln.ac.nz)

Received 29 March 2012 | Accepted 3 April 2012 | Published 16 May 2012

Citation: Cripps MG, Bourdôt GW, Bailey KL (2012) Plant pathogens as biocontrol agents for Cirsium arvense - an answer to Müller and Nentwig. NeoBiota 13: 31-39. doi: 10.3897/neobiota.13.3137

Recently, Müller and Nentwig (2011) reviewed the plant pathogens that have been considered for biological control of the weed Cirsium arvense (L.) Scop. (Canada thistle, Californian thistle, creeping thistle), and concluded that the prospects have been largely overestimated. The premise of their conclusion is that no bioherbicide products have achieved marketability, which they surmise is due to lack of host specificity, effectiveness, and issues with application. While it is true that no microbial products have achieved marketability for this weed, we believe their reasoning for this is erroneous, and likely due to lack of distinction between two biocontrol approaches, specifically classical biocontrol, and innundative biocontrol (often referred to as the biopesticide approach). These two different types of biocontrol have different goals, and are applied in different ways.

Generally, in classical biocontrol, coevolved insects or pathogens from the native range of a weed are imported and released in regions where the weed has been introduced, and has become invasive (McFadyen 1998; Watson 1991). Classical biocontrol is permanent, and when successful, requires little or no continued management input. The goal is not eradication, but rather to suppress weed populations to a level where they are no longer problematic. When importing natural enemies (insects or microbes), assurance of safety to non-target plants is paramount, and often requires a high degree of host specificity (Barton 2004; Berner and Bruckart 2005).

Copyright Michael G. Cripps et al. This is an open access article distributed under the terms of the Creative Commons Attribution License 3.0 (CC-BY), which permits unrestricted use, distribution, and reproduction in any medium, provided the original author and source are credited. 
In the introduction to their paper, Müller and Nentwig (2011) summarise the insect biocontrol agents that have been released (classical biocontrol agents) (Cripps et al. 2011), and noted a gap in the review literature, the potential of pathogens as biocontrol agents. However, since they failed to explain the two biocontrol approaches it is worth noting that to date no microbial pathogens have been intentionally released as classical biocontrol agents for $C$. arvense, although there is a current active program searching for potential pathogens suitable for release as classical agents against this weed. Recent foreign exploration has been focused in north-western China, a little explored region of the native range of $C$. arvense. Potential classical biocontrol pathogens include the white blister rust, Pustula cf. spinulosa and more aggressive strains of the rust, Puccinia punctiformis ( $\mathrm{Li}$ et al. 2011). Ongoing tests with these, and other pathogens, will determine if they are suitable for release as classical biocontrol agents (H. Hinz, personal communication).

Other than the recent initiative to find classical biocontrol pathogens, all of the microbes researched to date, including all those reviewed by Müller and Nentwig, have been considered for innundative control, or microbial agents that could be utilised as bioherbicides. This is a different type of biocontrol compared to the importation and release of natural enemies from the native range. In contrast, innundative biocontrol typically does not involve importing new species, but rather utilises species already present, often cosmopolitan generalist microbial pathogens. Innundative biocontrol involves the mass release or application of a pathogen, typically in the same manner as conventional pesticides. The goal is short term (e.g. growing season), but substantial control, that will often require repeated applications.

\section{Specificity of bioherbicides}

Müller and Nentwig insistently raised the issue of specificity and claimed that: "The primary reason for the failure of most of the tested plant pathogens against $C$. arvense is the missing host specificity". There are many constraints in the development and registration of bioherbicies, but least among these is specificity (Auld and Morin 1995). The most successful bioherbicides of the past 30 years (e.g. DeVine, COLLEGO, BioMal, Chontrol) are not host-specific, but capable of infecting a relatively broad range of plant species (Bailey 2010; Charudattan 1990). Despite their broad host range, a thorough understanding of the biology and epidemiology of the pathogens has allowed their use without any adverse effects to non-target plants, or environmental hazards. Bioherbicides are intended to be used in selected sites, with care taken to avoid areas with potentially susceptible non-target plants, as indicated on the product label. The pathogens selected for development into bioherbicide products do not naturally spread far from their site of application, which is why they need to be spread, typically by using conventional pesticide application equipment, in order to be effective.

Sclerotinia sclerotiorum is an example of a fungal pathogen with a broad host range, but suitable for use as a bioherbicide to control C. arvense in permanent pastures. Un- 
fortunately, Müller and Nentwig (2011) misconstrued some of the studies with this pathogen in their statement: "...as its spores spread easily, its use on pastures may cause hazards after changes of land use and for adjacent areas, even if a safety zone is allowed." Contrary to their interpretation, the risk analysis revealed that the use of this pathogen in pastures in New Zealand presents little or no risk to adjacent downwind crops due to the spore-trapping ability of the pastures combined with the ubiquitous nature of this pathogen and its relatively high ambient atmospheric spore density (Bourdôt et al. 2006 and Bourdôt et al. 2011).

Another example of a broad spectrum fungal pathogen capable of controlling $C$. arvense in certain situations such as cereal crop production is Phoma macrostoma (Zhou et al. 2004). This pathogen is applied to the soil as a pre-emergent bioherbicide capable of controlling many herbaceous weeds, but does not harm most Poaceae species, making it an attractive alternative for broadleaf weed control where common phenoxy herbicides are no longer desirable or permitted for use (Bailey et al. 2011a). Safety to non-target plants is assured when used in selected situations since the infective propagule applied is mycelium that has limited mobility and weak persistence (Bailey et al. 2011b).

In their conclusion, Müller and Nentwig mentioned the possibility of unintended impacts on native, non-target thistle species. This indeed was a problem with the classical biocontrol insect, Rhinocyllus conicus (Gassmann and Louda 2001); however, there is no reason to believe that the prudent use of microbial pathogens as bioherbicides would have similar non-target impacts. This further emphasises the need to clearly distinguish the type of biological control intended when discussing host specificity requirements, and potential non-target effects.

Pathogens with broad spectrum activity are currently preferred from a commercial developmental perspective, since host-specific pathogens have limited market potential. For instance, the host-specific rust pathogen, Puccinia thlaspeos, was registered as a bioherbicide for control of Isatis tinctoria (dyer's woad) (US-EPA 2002), but never became a commercial product due to lack of investor interest in such a specialised product (Bellgard 2008). Nevertheless, if demand was great enough, and the product produced cheaply enough, a bioherbicide based on a host-specific pathogen could be a viable product. Given that $C$. arvense is a particularly troublesome weed of global significance (Tiley 2010), a bioherbicide based on a host-specific pathogen could be a viable product, particularly if alternatives to synthetic herbicides are desired. The hostspecific rust pathogen, Puccinia punctiformis, has long been considered a potential biocontrol agent of $C$. arvense (Frantzen 1994), and conceivably could be formulated into a product in much the same way as $P$. thlaspeos, using dried, mulched, rust-infected plants (Thomson and Kropp 2004).

Müller and Nentwig (2011) also mentioned problems with "application possibilities", although they did not elaborate on what they meant by this. We imagine they might be referring to the inability to culture inoculum of the fungus, P. punctiformis. Whilst the strict host specificity and obligate biotrophic nature of $P$. punctiformis are constraints on its development as a bioherbicide, it does not rule out the possibility of 
augmenting the effect of natural infestations of this fungus on $C$. arvense. Augmentation of the effect of this pathogen has been hampered by an incomplete understanding of how systemic infection is initiated (Cripps et al. 2009; Frantzen 1994). Nevertheless, enhancement of systemic rust disease has been achieved by spreading its spores during strategic mowing operations (Demers et al. 2006), and it is plausible that this effect could be enhanced further by mowing during rainfall (Bourdôt et al. 2011a).

\section{Effectiveness of bioherbicides}

Müller and Nentwig claimed that "the varying and low virulence of the pathogens pose a problem (e.g., Alternaria cirsinoxia, Sclerotinia sclerotiorum, Phomopsis cirsii) as constant levels of virulence must be ensured for a successful inhibition of the growth of the target weed." In the case of $A$. cirsinoxia, lack of efficacy, due to the inability of the pathogen to infect young leaves, and defensive mechanisms of the plant, were reasons this pathogen was considered unsuitable for bioherbicide development (Bailey 2004). However, the efficacies of $S$. sclerotiorum, $P$. cirsii, and many other pathogens, are not a limiting factor for their development into bioherbicides. Müller and Nentwig's assumption that low and varying efficacy has prevented bioherbicides from commercialisation lacks a standard for comparison. The efficacy of synthetic herbicides might be considered a benchmark for measuring the effectiveness of bioherbicides, and would at least offer comparison to current control products that bioherbicides could replace or compete with.

Considerable variation among synthetic herbicides for controlling $C$. arvense has been well documented (Donald 1990). As a recent example, Enloe et al. (2007) compared several standard commercial herbicides for control of $C$. arvense and reported that control ranged from 34 to 97 percent. Variation in the efficacy of particular herbicides for the control of $C$. arvense also varies with many factors including phenology of the weed (Miller and Lym 1998), season of application (Wilson et al. 2006), environmental factors (Hunter and Smith 1972), and resistant ecotypes (Donald 1990). Thus, although reliability in the efficacy of a weed control product is highly desirable, it is often not realised in practice, even with currently marketed synthetic herbicides.

In particular, the variability in efficacy of a potential bioherbicide product based on Sclerotinia sclerotiorum was compared with two phenoxy herbicides, MCPA and MCPB. It was shown that the bioherbicide was no more variable in its efficacy under field conditions than the two synthetic herbicides and on average just as effective as MCPA (Bourdôt et al. 2007). Similar responses were observed in field trials using $P$. macrostoma and the standard herbicide mixture of 2,4-D, mecoprop and dicamba such that both products provided greater than $80 \%$ control of dandelion in $75 \%$ of the trials (unpublished data, K. Bailey).

While considerable variation is often reported in the discovery and proof-of-concept stages for a potential bioherbicide, much of the variation can be reduced by selecting particular aggressive strains, and by amending the final formulation with adjuvants that enhance and protect the pathogen (Ash 2010; Weaver et al. 2007). This was 
demonstrated for $P$. cirsii as selected fungal strains were shown to be highly pathogenic (Leth et al. 2008), and adjuvants reduced the long necessary dew period that limited its potential (Leth and Andreasen 2000).

Another important point that Müller and Nentwig (2011) failed to emphasise is that $C$. arvense is difficult to control by any means, including biological and synthetic herbicides (Donald 1990; Tiley 2010). Control of C. arvense often requires multiple herbicide applications over several years (Donald 1990; Donald 1992), and can be improved by integrating herbicides with other techniques such as cultural (e.g. tillage and mowing), (Beck and Sebastian 2000) and biological control (Sciegienka et al. 2011). Thus, while bioherbicides on their own may not be the solution to control of $C$. arvense, their efficacy is not worse than other current control measures, and certainly not the reason for their absence.

\section{Why are there no bioherbicides for Cirsium arvense?}

With so much potential, why are there no bioherbicides for control of this important weed? The general dearth of bioherbicides has been addressed by other authors (Hallett 2005), and in essence the reasons are bureaucratic and economic issues. The bureaucratic issues lie primarily with the onerous and costly government registration procedures that require bioherbicides to provide the same information necessary for synthetic herbicides such as human and environmental toxicology reports (Bailey 2010). However, more recently, some government agencies have relaxed their registration procedures for biologically-based and other reduced-risk pesticides relative to the procedures required for new conventional pesticides in order to promote the development of lower-risk products (Bailey et al. 2010). The major impediment to the development of bioherbicides is the assurance of profitability to commercial investors. And the main limitation to profitability is the cost of production, which for fungi typically involves solid-state or liquid fermentation on some sort of nutrient medium (Weaver et al. 2007). Similarly, the most common reason for discontinuation of previously marketed bioherbicides is that the cost of production is too high, and the market too small to justify production costs.

It is important to remember that contrary to classical biocontrol where agents (insects or pathogens) are released for common good without proprietary right, the intention of innundative biocontrol is the development of a bioherbicide product that can be sold for profit in a competitive market (Auld 1991). This competitive herbicide market is currently dominated by cheaply-available glyphosate and phenoxy herbicides, which has been suggested as a primary reason for the absence of new synthetic herbicide modes of action over the past 20 years (Duke 2012). Bioherbicides offer increased safety and sustainability, however, these values are more difficult to quantify. In order for bioherbicides registered for use against $C$. arvense to reach the market place there will likely need to be increased demand for alternative products through legislation restricting synthetic herbicides, and by placing greater value on the safety and sustainability aspects of bioherbicides (Boyetchko and Rosskopf 2006; Charudattan 2001). 


\section{Conclusions}

Müller and Nentwig (2011) can be commended for undertaking a review of an important subject not thoroughly dealt with in other recent reviews, and for covering most microbial pathogens that have been considered for biocontrol of $C$. arvense. However, we disagree with their conclusion that microbial control of this weed has been largely overestimated. We believe their conclusion is based on erroneous reasoning and a disconnection with contemporary perspectives on bioherbicides. The unfortunate consequence of such an ill-informed review is that readers are left with the false impression that bioherbicides are not a viable option for $C$. arvense control, and possibly other weeds as well. Contrary to Müller and Nentwig's reasoning, we have argued that specificity and efficacy of microbial biocontrol agents are not major limitations to their development as bioherbicides for $C$. arvense. Our perspective is that bioherbicide development is an underdeveloped approach with great potential, rather than overestimated.

\section{References}

Ash GJ (2010) The science, art and business of successful bioherbicides. Biological Control 52: 230-240. doi: 10.1016/j.biocontrol.2009.08.007

Auld BA (1991) Economic aspects of biological weed control with plant pathogens. In: TeBeest DO (Ed) Microbial control of weeds. Chapman and Hall, London, 262-273. doi: 10.1007/978-1-4615-9680-6_14

Auld BA, Morin L (1995) Constraints in the development of bioherbicides. Weed Technology 9: 638-652.

Bailey KL (2004) Microbial weed control: an off-beat application of plant pathology. Canadian Journal of Plant Pathology 26: 239-244. doi: 10.1080/07060660409507140

Bailey KL (2010) Canadian innovations in microbial biopesticides. Canadian Journal of Plant Pathology 32: 113-121. doi: 10.1080/07060661.2010.484195

Bailey KL, Boyetchko SM, Langle T (2010) Social and economic drivers shaping the future of biological control: A Canadian perspective on the factors affecting the development and use of microbial biopesticides. Biological Control 52: 221-229. doi: 10.1016/j.biocontrol.2009.05.003

Bailey KL, Pitt WM, Falk S, Derby J (2011a) The effects of Phoma macrostoma on nontarget plant and target weed species. Biological Control 58: 379-386. doi: 10.1016/j.biocontrol.2011.06.001

Bailey KL, Pitt WM, Leggett F, Sheedy C, Derby J (2011b) Determining the infection process of Phoma macrostoma that leads to bioherbicidal activity on broadleaved weeds. Biological Control 59: 268-276. doi: 10.1016/j.biocontrol.2011.06.019

Barton J (2004) How good are we at predicting the field host-range of fungal pathogens used for classical biological control of weeds? Biological Control 31: 99-122. doi: 10.1016/j. biocontrol.2004.04.008 
Beck KG, Sebastian JR (2000) Combining mowing and fall-applied herbicides to control Canada thistle (Cirsium arvense). Weed Technology 14: 351-356. doi: 10.1614/0890-037X(2 000)014[0351:CMAFAH]2.0.CO;2

Bellgard S (2008) Innundative control using bioherbicides. In: The biological control of weeds book. Landcare Research, NZ.

Berner DK, Bruckart WL (2005) A decision tree for evaluation of exotic plant pathogens for classical biological control of introduced invasive weeds. Biological Control 34: 222-232. doi: 10.1016/j.biocontrol.2005.04.012

Bourdôt GW, Baird D, Hurrell GA, De Jong MD (2006) Safety zones for a Sclerotinia sclerotiorum-based mycoherbicide: Accounting for regional and yearly variation in climate. Biocontrol Science and Technology 16: 345-358. doi: 10.1080/09583150500531966

Bourdôt GW, Hurrell GA, Saville DJ (2007) Variation in the efficacy of a mycoherbicide and two synthetic herbicide alternatives. In: Julien HH et al. (Eds) XII th International Symposium on Biological Control of Weeds. CAB InternationalWallingford, UK, La Grande Motte, Montpellier, France, 507-511.

Bourdôt GW, Hurrell GA, Skipp RA, Monk J, Saville DJ (2011a) Mowing during rainfall enhances the control of Cirsium arvense. Biocontrol Science and Technology 21: 1213-1223. doi: 10.1080/09583157.2011.608119

Bourdôt GW, Saville DJ, De Jong MD (2011b) Evaluating the environmental safety of broad host range bioherbicides (invited paper). Pest Technology 5 (Special issue 1): 34-40.

Boyetchko SM, Rosskopf EN (2006) Strategies for developing bioherbicides for sustainable weed management. In: Singh HP, Batish DR, Kohli RK (Eds) Handbook of sustainable weed management, 393-430.

Charudattan R (1990) Pathogens with potential for weed control. In: Hoagland RE (Ed) ACS Symposium Series 439. American Chemical Society, Washington, DC, 132-154. doi: 10.1023/A:1011477531101

Charudattan R (2001) Biological control of weeds by means of plant pathogens: Significance for integrated weed management in modern agro-ecology. Biocontrol 46: 229-260.

Cripps MG, Edwards GR, Waipara NW, Bourdôt GW, Saville DJ, Fowler SV (2009) Does transmission of the rust pathogen, Puccinia punctiformis, require stem mining vectors? Biocontrol Science and Technology 19: 447-454. doi: 10.1080/09583150802699420

Cripps MG, Gassmann A, Fowler SV, Bourdôt GW, McClay AS, Edwards GR (2011) Classical biological control of Cirsium arvense: Lessons from the past. Biological Control 57: 165-174. doi: 10.1016/j.biocontrol.2011.03.011

Demers AM, Berner DK, Backman PA (2006) Enhancing incidence of Puccinia punctiformis, through mowing, to improve management of Canada thistle (Cirsium arvense). Biological Control 39: 481-488. doi: 10.1016/j.biocontrol.2006.06.014

Donald WW (1990) Management and control of Canada thistle (Cirsium arvense). Reviews of Weed Science 5: 193-250.

Donald WW (1992) Herbicidal control of Cirsium arvense (L.) Scop. roots and shoots in no-till spring wheat (Triticum aestivum L.). Weed Research 32: 259-266. doi: 10.1111/j.13653180.1992.tb01885.x 
Duke SO (2012) Why have no new herbicide modes of action appeared in recent years? Pest Management Science 68: 505-512. doi: 10.1002/ps.2333

Enloe SF, Lym RG, Wilson R, Westra P, Nissen S, Beck G, Moechnig M, Peterson V, Masters RA, Halstvedt M (2007) Canada thistle (Cirsium arvense) control with aminopyralid in range, pasture, and noncrop areas. Weed Technology 21: 890-894. doi: 10.1614/WT-07-004.1

Frantzen J (1994) An epidemiological study of Puccinia punctiformis (Str.) Röhl as a steppingstone to the biological control of Cirsium arvense (L.) Scop. New Phytologist 127: 147-154. doi: 10.1111/j.1469-8137.1994.tb04269.x

Gassmann A, Louda SM (2001) Rhinocyllus conicus: initial evaluation and subsequent ecological impacts in North America. In: Wajnberg E, Scott JK, Quimby PC (Eds) Evaluating indirect ecological effects of biological control. CABI Publishing, Wallingford, Oxon, 147-183.

Hallett SG (2005) Where are the bioherbicides? Weed Science 53: 404-415. doi: 10.1614/ WS-04-157R2

Hunter JH, Smith LW (1972) Environment and herbicide effects on Canada thistle ecotypes. Weed Science 20: 163-167.

Leth V, Andreasen C (2000) Alginate helps Phomopsis cirsii Grove to overcome short dew periods. In: BIO-Y2K Combined Millenium Meeting, Grahamstown, South Africa, 563-564. doi: 10.1111/j.1365-3180.2008.00666.x

Leth V, Netland J, Andreasen C (2008) Phomopsis cirsii: a potential biocontrol agent of Cirsium arvense. Weed Research 48: 533-541.

Li H, Wan H, Evans HC, Ellison C, Hinz HL, Zhang Y, Zhang F (2011) Biological control of Canada thistle, Cirsium arvense. CABI Annual Report 2010.

McFadyen REC (1998) Biological Control of Weeds. Annual Review of Entomology 43: 369-393. doi: 10.1146/annurev.ento.43.1.369

Miller BR, Lym RG (1998) Using the rosette technique for Canada thistle (Cirsium arvense) control in row crops. Weed Technology 12: 699-706.

Muller E, Nentwig W (2011) Plant pathogens as biocontrol agents of Cirsium arvense - an overestimated approach? NeoBiota 11: 1-24. doi: 10.3897/neobiota.11.1803

Sciegienka JK, Keren EN, Menalled FD (2011) Interactions between two biological control agents and an herbicide for Canada thistle (Cirsium arvense) suppression. Invasive Plant Science and Management 4: 151-158. doi: 10.1614/IPSM-D-10-00061.1

Thomson SV, Kropp BR (2004) Production of Puccinia thlaspeos "woad" strain inoculum using traditional farming equipment. Phytopathology 94: S155-S155.

Tiley GED (2010) Biological Flora of the British Isles: Cirsium arvense (L.) Scop. Journal of Ecology 98: 938-983. doi: 10.1111/j.1365-2745.2010.01678.x

US-EPA (2002) Puccinia thlaspeos 'strain woad'. US Enviromental Protection Agency, Office of Pesticide Programs.

Watson AK (1991) The classical approach with plant pathogens. In: TeBeest DO (Ed) Microbial control of weeds. Chapman and Hall, London, 3-23. doi: 10.1007/978-1-4615-9680-6_1

Weaver MA, Lyn ME, Boyette CD, Hoagland RE (2007) Bioherbicides for weed control. In: Upadhyaya MK, Blackshaw RE (Eds) Non-chemical weed management. CAB International, 93-110. 
Wilson RG, Martin AR, Kachman SD (2006) Seasonal changes in carbohydrates in the root of Canada thistle (Cirsium arvense) and the disruption of these changes by herbicides. Weed Technology 20: 242-248. doi: 10.1614/WT-05-052R1.1

Zhou LC, Bailey KL, Derby J (2004) Plant colonization and environmental fate of the biocontrol fungus Phoma macrostoma. Biological Control 30: 634-644. doi: 10.1016/j.biocontrol.2004.03.002 